\title{
Effect of Integrated Nutrients Management and Iodine Fertilization on Sulphur Content in Spinach (Spinacea oleracea L.)
}

\author{
Shishu Pal Singh ${ }^{1 *}$, Shivraj Singh ${ }^{2}$, Vimal Kumar ${ }^{1}$, \\ Ravindra Kumar Rajput ${ }^{3}$ and Mohan Singh ${ }^{4}$ \\ ${ }^{I}$ Department of Agriculture, Utter Pradesh Government, Krishi Bhavan Varanasi, India \\ ${ }^{2}$ PG College Ghazipur, Ravindrapuri, Ghazipur, Uttar Pradesh, India \\ ${ }^{3}$ Krishi Vigyan Kendra Mathura, India \\ ${ }^{4}$ Krishi Vigyan Kendra (KVK), Moradabad, India \\ *Corresponding author
}

\section{A B S T R A C T}

A greenhouse pot experiment was conducted at the Department of Soil Science and Agricultural Chemistry, Institute of agricultural Sciences, Banaras Hindu University,

\section{Keywords}

Spinach, Organic fertilizer, Sulphur Content

Article Info

Accepted:

20 January 2018

Available Online:

10 February 2018
Varanasi to study of the effect of iodine fertilization (Iodine and Iodates) the levels (0.0. 1.0.2.5 and $5.0 \mathrm{mg} \mathrm{kg}^{-1}$ ) in combination of recommended dose of Nitrogen Phosphorus, Potassium and Nitrogen Phosphorus, Potassium With Farm Yard Manure on Calcium, Magnesium and Sulphur content in spinach (Spinacea oleracea L.) Fortification of iodine with the application of potassium iodide/iodine in spinach with recommended doses of fertilizers (NPK)/NPK + FYM significantly improved the Secondary nutrient content (Calcium, Magnesium and Sulphur) in Spinace leaves. A increasing trend were observed in the sulphur content of spinach leaf when iodine applied with recommended dose of NPK at both the harvesting stages particularly in the form of iodate and the highest sulphur content was observed @ $5.0 \mathrm{mg} \mathrm{kg}^{-1}$ in both the forms of iodine. Application of FYM and inorganic fertilizers alone and in combination had a significant effect on sulphur content. Thus, the overall result suggests that spinach can be cultivated in soil treated with chemical fertilizer in combination with Farm Yard Manure for higher yield and to improve the soil fertility and productivity.

\section{Introduction}

Spinach (Spinacea oleracea L.) is an edible flowering plant in the family of Chenopodiaceae. It is native to central and Southwestern Asia. It is an annual plant (rarely biennia), which grows to a height of up to $30 \mathrm{~cm}$. Spinach may survive over winter in temperate region. The leaves are alternate, simple ovate to triangular based very variable in size from about 2-30 cm long and $1-15 \mathrm{~cm}$ broad, with larger leaves at the base of the plant and small leaves higher on the flowering stem. Spinach is a low growing fleshly leaved annual that forms a heavy rosette of either smooth or wrinkled leaves. Vegetables, especially those of leafy vegetable grown in heavy metals contaminated soils because of the fact they absorb these metals through their leaves. Spinach has a high nutritional value and is extremely rich in antioxidants, especially when fresh, steamed, or quickly boiled it is a rich source of vitamin A (and especially high in lutein), vitamin $\mathrm{C}$, vitamin 
$\mathrm{E}$, vitamin $\mathrm{K}$, magnesium, manganese, folate, betaine, iron, vitamin B2, calcium, potassium, vitamin B6, folic acid, copper, protein, phosphorus, zinc, niacin, selenium and omega3 fatty acids Recently, opioid peptides called rubiscolins have also been found in spinach.

According to WHO and FAO, an adult person's diet should contain $250 \mathrm{~g}$ vegetable per day. Vegetables are produced at present which are too low against our demand (DAE, 1995). Fertilizers are essential part of modern farming system, about $50 \%$ of the world production being attributed to fertilizer use and it may be a source of the environmental and soil degradation (Pradhan, 1992). Minerals and vitamins are essential protective nutrients for maintenance of nutritional and health status of the body. They cannot be synthesized in the human body and, therefore, they must be obtained through diet. The composition of nutrient content of the vegetables varies widely depending on the part of the plant used as food (Hughes and Marion, 1970) Generally, vegetables are considered to contribute appreciable amounts of minerals and vitamins; but when compared with other groups of vegetables, green leafy vegetables are known to be exceptionally rich in minerals, $\beta$-carotene (Duckworth, 1966) and are also a good source of dietary fiber and antioxidants (Svanberg and Nyman, 1997; Schneeman, 1989). Green leafy vegetables, in general, are inexpensive foods rich in minerals and vitamins. Specifically, it is also well known that nutrient elements in the leaves of spinach are always important to human health (Welch, 2002). Spinach as a dietetic nutrient has long been the object of many investigators. Spinach is the commonly consumed green leafy vegetables in different parts of India.

The findings from various studies conducted by several groups of investigators revealed that content of minerals in plant foods can be altered by the application of fertilizers to the soil by balancing the macronutrients and with micronutrients (Kongale, 1986; Summai et al., 1980; Patel et al., 1997). However, most of this research was carried out with foods other than vegetable crops. Hence, the present study was undertaken to find the effect of addition of chemical fertilizers and in combination, chemical fertilizer and FYM to soil on mineral contents of most popular green leafy vegetable, spinach (Spinacea oleracea $\mathrm{L}$.). In addition, the spinach was tried to fortify iodine by the application potassium iodide/potassium iodate in soil. Thus, iodine was applied in soil in addition chemical fertilizer/chemical fertilizer + FYM. Although iodine is not essential element to plant, but iodine is an important essential micronutrient element for human being and animals. It require for synthesis of thyroid hormones, thyroxins and triiodothyroxin which are iodinated molecules of the amino acid tyrosine. Consumption of crops and plants grown in iodine deficient soils leads to iodine deficiency. It is now established that iodine deficiency in human being and animal occurs only in the areas where vegetation is poor in iodine. Hence, iodine rich salt supplement is recommended to ward off iodine deficiency disorder. But during cooking with high temperature oil will result in the volatilization of Iodine (Zhang et al., 2000). The present study was undertaken to find the effect of iodine application through potassium iodide/potassium iodate in addition to fertilization on the yield and micronutrient contents of spinach.

\section{Materials and Methods}

Geographically, the district Varanasi is situated at $25^{\circ} 18^{\prime}$ of northern latitude, $83^{\circ} 36^{\prime}$ of Eastern longitude and at an altitude of $80.71 \mathrm{~m}$ above the mean sea level in the IndoGangetic plain of eastern Uttar Pradesh. The district Varanasi having alluvial soil lies in a semi-arid region to sub-humid belt of northern 
India. The district is surrounded by district St. Ravidas Nagar in the east, Chandauli in the west, Jaunpur in north and Mirzapur district in the south. The present investigation involved a pot experiment followed by laboratory analysis of the plant and soil at the Department of Soil Science and Agricultural Chemistry, Institute of Agricultural Sciences, Banaras Hindu University, Varanasi.

The experimental soil was sandy loam with $2.25 \mathrm{mg} \mathrm{kg}^{-1}$ available iodine, $1.43 \mathrm{Mg} \mathrm{m}^{-3}$ bulk density, $2.56 \mathrm{Mgm}^{-3}$ particle density, $45.40 \%$ water holding capacity, $7.8 \mathrm{pH}, 0.254$ $\mathrm{dS} \mathrm{m}^{-1}$ electrical conductivity, $6.21 \mathrm{~g} \mathrm{~kg}^{-1}$ organic matter, $11.04 \mathrm{C} \mathrm{mol}(\mathrm{p}+) \mathrm{kg}^{-1}$ cation exchange capacity and 197.27, 19.09, 203.54, $19.77 \mathrm{~kg} \mathrm{ha}^{-1}$ of available $\mathrm{N}, \mathrm{P}, \mathrm{K}, \mathrm{S}$, respectively and the soil was characterized by standard method (Jackson, 1967). The pot experiment was planned in a greenhouse with temperature of $28 \pm 3^{\circ} \mathrm{C}$ during the day and 18 $\pm 3^{\circ} \mathrm{C}$ at night. $1.0 \mathrm{~kg}$ well pulverized soil was filled in each pot. The recommended doses of N, P, K (80:50:50) fertilizers were applied in each pot through urea, single super phosphate and muriate of potash, respectively with different levels and sources of iodine in combination with and without FYM (1\% organic carbon). Potassium iodide and potassium iodate were used as an iodine fertilizer for iodine treatments. $100 \mathrm{mg} \mathrm{I} \mathrm{L}^{-1}$ of potassium iodide and iodate were prepared as stock solution then $0.0,1.0,2.5$ and $5.0 \mathrm{mg}$ $\mathrm{kg}^{-1}$ iodine solution was applied at 20 DAS in respective pots. Full dose of phosphorus, potassium and $1 / 3$ dose of nitrogen were applied at the time of pot filling through mixing and rest $\mathrm{N}$ was applied into two split doses at 20 and 30 days after seed sowing, respectively. The plants were grown in green house, keeping moisture level $50 \%$ of the field capacity with de-ionized water at regular interval. 5-6 healthy seeds of spinach were shown at proper depth in the month of December and after germination 3 plants in each pot was maintained at 15 days after sowing (DAS). Experimental samples were collected into two stages, 45 and 60 DAS. The fresh weight of edible portion of spinach was taken after harvesting at 45 and 60 DAS.

\section{Processing and digestion of plant sample}

The surface moisture of plant leaf samples were blotted in ordinary filter paper. After air drying, plant samples were stored in packets with pencil labelling. After hot air oven drying $\left(65^{\circ} \mathrm{C}\right)$ the samples has been grinded and then was stored in desiccator (fused $\mathrm{CaCl}_{2}$ was in the bottom) for further chemical analysis. Weighed $0.5 \mathrm{~g}$ of oven dried and processed leaf sample of spinach was taken in a $35 \mathrm{~cm}$ digestion tube. $10 \mathrm{~mL}$ of concentrated $\mathrm{HNO}_{3}$ was added for each sample and kept overnight at a covered place/chamber for pre-digestion. After pre-digestion when sample dissolved in $\mathrm{HNO}_{3}, 10 \mathrm{~mL}$ of concentrated $\mathrm{HNO}_{3}$ and 2-3 $\mathrm{mL}$ of $\mathrm{HClO}_{4}$ were added in the same tube. The tubes was placed on a hot plate in acid proof digestion chamber having fume exhaust system and heated at about $100^{\circ} \mathrm{C}$ (KEL PLUS KES 20 model plant digestion system) for first one hour and then raised the temperature of about $200^{\circ} \mathrm{C}$. Digestion continued until the contents became colourless and only white dense fumes appeared. The acid contents were reduced in digestion tubes to about $2-3 \mathrm{~mL}$ by continuous heating at the same temperature. After removing the tubes from hot plate, cooled it and $10 \mathrm{~mL}$ of $2 \mathrm{~N} \mathrm{HCl}$ was added to each tube. Digestion continued for by warmed the content slightly for some time. The samples were then filtered through Whatman No. 42 filter paper into a $50 \mathrm{~mL}$ volumetric flask then made up the volume to $50 \mathrm{~mL}$ through 3-4 times washing of filter paper through distilled water.

\section{Determination of sulphur content in spinach plant}

Sulphur content in plant was determined by barium sulphate turbidity method. $10 \mathrm{~mL}$ of 
plant digested sample was taken in $50 \mathrm{~mL}$ conical flask. Then $1.0 \mathrm{~mL} 6 \mathrm{~N} \mathrm{HCl}$ and $1 \mathrm{~mL}$ of $0.5 \%$ gum acacia solutions were added. The content was mixed by swirling and then added $0.5 \mathrm{~g}$ barium chloride crystals. The flasks were allowed to stand for one minute and then swirled the contents gently until the barium chloride crystals are dissolved. The turbidity of the samples were measured (Chesnin and Yein, 1950) through ELICO; SL-164, Double beam spectrophotometer. The turbidity of standard series $\left(\mathrm{K}_{2} \mathrm{SO}_{4}\right)$ was also measured simultaneously.

\section{Results and Discussion}

Fertilizer feeds the world through feeding the soils and in turn plants and if the world is not to go hungry, fertilizers will continue to play the key role in food production. No country in the world has been able to increase agricultural productivity and quality of foods without expanding the use of mineral fertilizers. In India, contribution of fertilizers towards increase in foodgrain production is estimated to be 50 per cent (Tiwari, 2007) Horticultural crops have a tremendous potential for fertilizer use. These are heavy feeders of plant nutrients and number of crops may absorb 500-1000 kg N $+\mathrm{P}_{2} \mathrm{O}_{5}+$ $\mathrm{K}_{2} \mathrm{O} /$ ha/year or even more under good management condition (Tandon, 1991) Nutrient uptake by many vegetable crops is equal to or high than that of cereal crops.

To replenish the removal and to supply sufficient amount of nutrients at each stage of crop growth, adequate rates are needed in the fertilizer application programme of horticultural crop (Kemmler and Tandon, 1998). Beside major nutrients, fortification of human essential micronutrients, viz. Fe, Zn, I through fertilizer is also gaining importance in nutrient management system

Table.1 Effect of fertilization and iodine application on sulphur content in spinach

\begin{tabular}{|c|c|c|}
\hline \multirow[t]{2}{*}{ Particulars } & \multicolumn{2}{|c|}{$\begin{array}{l}\text { Effect of Fertilization and Iodine Application } \\
\left.\text { on Sulphur Content in Spinach ( } \mathrm{mg} \mathrm{kg}^{-1}\right)\end{array}$} \\
\hline & 45 Days After Sowing & 60 Days After Sowing \\
\hline \multicolumn{3}{|l|}{ Nutrient Sources } \\
\hline Chemical (NPK) & 0.430 & 0.570 \\
\hline $\begin{array}{l}\text { Chemical (NPK) + Organic } \\
\text { (FYM) }\end{array}$ & 0.440 & 0.550 \\
\hline $\mathrm{SEm} \pm$ & 0.0110 & 0.007 \\
\hline $\mathrm{CD}(\mathrm{P}=0.05)$ & NS & NS \\
\hline \multicolumn{3}{|l|}{ Iodine Sources/Doses } \\
\hline Control & 0.350 & 0.400 \\
\hline $\mathrm{KI}-1.0 \mathrm{mg} \mathrm{kg}^{-1}$ & 0.435 & 0.620 \\
\hline $\mathrm{KI}-2.5 \mathrm{mg} \mathrm{kg}^{-1}$ & 0.430 & 0.580 \\
\hline $\mathrm{KI}-5.0 \mathrm{mg} \mathrm{kg}^{-1}$ & 0.450 & 0.540 \\
\hline $\mathrm{KIO}_{3}-1.0 \mathrm{mg} \mathrm{kg}^{-1}$ & 0.470 & 0.630 \\
\hline $\mathrm{KIO}_{3}-2.5 \mathrm{mg} \mathrm{kg}^{-1}$ & 0.450 & 0.590 \\
\hline $\mathrm{KIO}_{3}-5.0 \mathrm{mg} \mathrm{kg}^{-1}$ & 0.460 & 0.550 \\
\hline $\mathrm{SEm} \pm$ & 0.021 & 0.013 \\
\hline$C D(P=0.05)$ & 0.050 & 0.030 \\
\hline
\end{tabular}


Table.2 Interaction (nutrient source $\times$ iodine source) effect on sulphur content in spinach

\begin{tabular}{|l|c|c|c|c|}
\hline \multirow{2}{*}{ Particulars } & \multicolumn{4}{|c}{ Sulphur Content in Spinach } \\
\cline { 2 - 5 } & $\begin{array}{c}\text { 45 Days After Sowing } \\
\text { Chemical } \\
\text { (NPK) }\end{array}$ & $\begin{array}{c}\text { Chemical } \\
\text { (NPK) } \\
\text { Organic } \\
\text { (FYM) }\end{array}$ & $\begin{array}{c}\text { Chemical } \\
\text { (NPK) }\end{array}$ & $\begin{array}{c}\text { Chemical } \\
\text { (NPK) }\end{array}$ \\
\hline Organic (FYM)
\end{tabular}

Fig.1 Effect of fertilization and iodine application on sulphur content in spinach

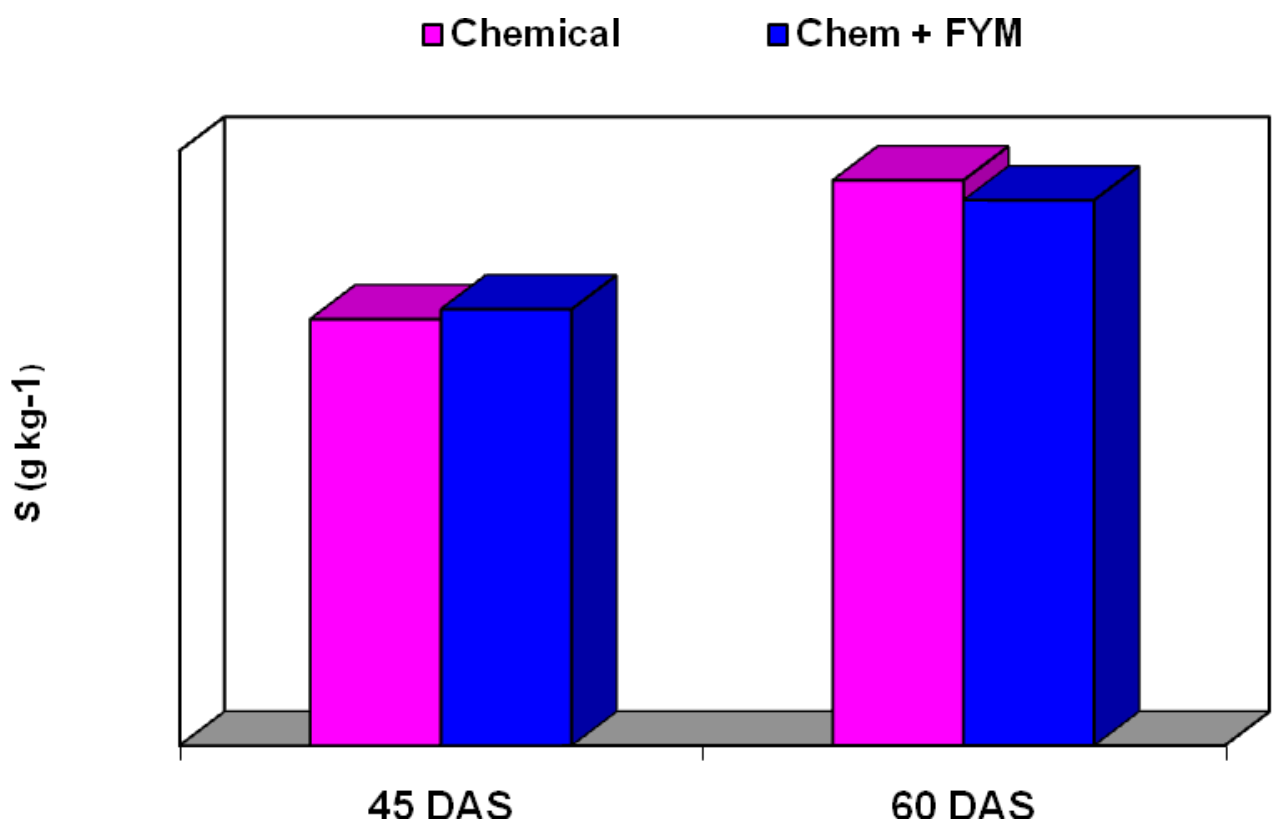




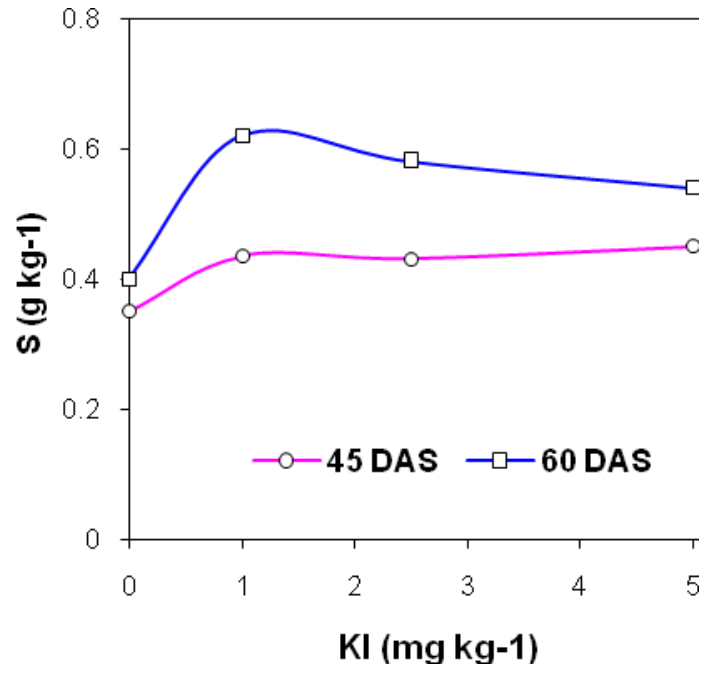

Effect of INM and iodine fertilization on sulphur content in spinach

Data on sulphur content in spinach corresponding to treatments are presented in Table 1 there was no significant variation on sulphur content in spinach between chemical fertilizer treatment and fertilizer + FYM treatment.

But, the sulphur content in spinach leaves was significantly increased (Fig. 1) by the application of iodine through $\mathrm{KI}$ and $\mathrm{KIO}_{3}$. The highest $\mathrm{S}$ content in leaves was observed when $\mathrm{KIO}_{3}$ applied @ $1.0 \mathrm{mg} \mathrm{kg}^{-1}$ at $60 \mathrm{DAS}$. The sulphur content increased 22.85 to $34.28 \%$ at 45 DAS and 25.92 to $57.50 \%$ at 60 DAS over control due to application iodine.

The interactive effects (nutrient sources $x$ iodine sources) on sulphur content was presented in Table 2. Browsing of data reveals that application of chemical fertilizer + FYM with iodine (irrespective of KI or $\mathrm{KIO}_{3}$ ) @ $1.0 \mathrm{mg} \mathrm{kg}{ }^{-1}$ increased highest concentration of $\mathrm{S}$ in plant at both the stages, 45 DAS and 60 DAS. Maximum sulphur was accumulated in leaves of the spinach at 60 DAS when iodine applied through $\mathrm{KIO}_{3}$, @ $1.0 \mathrm{mg} \mathrm{kg}^{-1}$ along with chemical fertilizer + FYM.

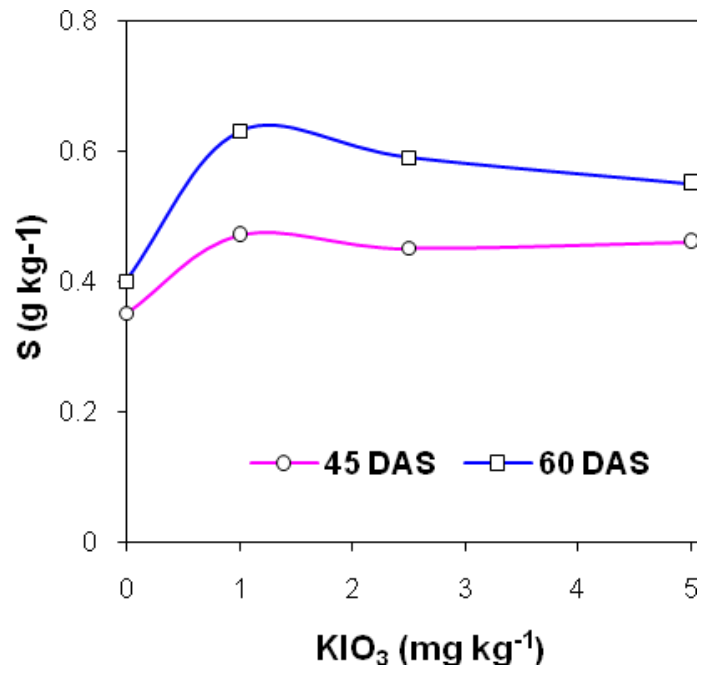

Various studies conducted by several groups of investigators revealed that content of minerals in plant can be altered by application of fertilizers to the soil by balancing the macronutrients and with micronutrients. However, most of this research was carried out with foods other than vegetable crops. Hence, the present study was undertaken to find the effect of addition of chemical fertilizers and in combination, chemical fertilizer and FYM to soil on Sulphur contents of most popular green leafy vegetable, Spinach (Spinacea oleracea L.). Some physico-chemical properties of soils (texture, bulk density, particle density, WHC, pH, EC, organic carbon, CEC, available $\mathrm{N}, \mathrm{P}, \mathrm{K}, \mathrm{S}$, total and available iodine) were analysed using standard analytical techniques for characterization of soils.

The nutrient contents in spinach were analysed after proper processing of plant samples. Sulphure in the plant samples was analysed by extracting $\mathrm{HNO}_{3}$ and $\mathrm{HClO}_{4}$. The sulphur in leaves of spinach was estimated by spectrophotometer. Fortification of iodine with the application of potassium iodide/iodine in spinach with recommended doses of fertilizers (NPK)/NPK + FYM significantly improved the sulphur content in leaves. 


\section{References}

DAE (Department of apicultural Extension). 1995. Training Manual: Vegetables and Spices Production. pp.: 45-47.

Dai, J. L., Zhu, Y. G., Zhang, M. and Huang, Y. Z. (2004). Selecting iodine-enriched vegetables and the residual effect of iodate application to soil. Biological Trace Elements Research 101(3): 265276

Duckworth, R.B. (1966) Fruits and Vegetables; Pergamon Press: Oxford, 1966; 142-159.

Hughes, O. and Marion, B. (1970) Introductory foods, $5^{\text {th }}$ Edn., The Mac Millan Co., London, 1970; 59-85.

Jackson, M.L. (1967) Soil Chemical Analysis, Prentice Hall, New Delhi

Kemmler, G. and Tandon, H.L.S. (1998) Potassium deficiency and its correction in horticultural crops. IPI, Berne and FDCO, New Delhi, pp. 23.

Kongale, N.V. (1986) Efficiency of boronated superphosphate in comparison with other phosphate sources for groundnut, sunflower and cauliflower. Dissertation submitted to Marathwada Agricultural University for M.Sc. (Agril.).

Patel, P.C., Patel, M.S. and Kalyan Sundaram, N.K. (1997) Effect of foliar spray of iron and sulphur on fruit yield of chlorotic acid lime. J. Ind. Soc. of Soil Sci., 45: 529-533.

Pauwels Borst G.W.F.H. (1961) Iodine as a micronutrient for plants. Journal of Plant and Soil XIV (4): 377-392.

Pradhan, S.B. 1992. Status of fertilizer use in developing countries of Asia and

\section{How to cite this article:}

Shishu Pal Singh, Shivraj Singh, Vimal Kumar, Ravindra Kumar Rajput3 and Mohan Singh. 2018. Effect of Integrated Nutrients Management and Iodine Fertilization on Sulphur Content in Spinach (Spinacea oleracea L.). Int.J.Curr.Microbiol.App.Sci. 7(02): 2355-2361. doi: https://doi.org/10.20546/ijcmas.2018.702.287
Pacific region. Proc. Reg. FADINAP seminar, Chaing, Mai, Thailand. pp. 3747.

Schneeman, B.O. (1989) Dietary Fiber. Food Tech. 43: 133-139.

Summai, R.C., Bhattacharya, P. and Das Gupta, S.K. (1980) Effect of zinc and iron on yield attributes of mustard (CVT 59). Indian Agriculturist, 24: 201-205

Svanberg, S.J.M. and Nyman, E.M.G.L. (1997) Effect of boiling and storage on dietary fiber and digestible carbohydrates in various cultivars of carrots. J. Sci. Food Agri., 73: 245-254.

Tandon, H.L.S. (1991) Fertilizer recommendations for horticultural crops - a guide book. 2nd edition. Fertilizer Development and Consultation Organization, New Delhi, pp. 104.

Tiwari, K.N. (2007) Reassessing the role of fertilizers in maintaining food, nutrition and environmental security. International Plant Nutrition Institute, April 2007, pp. 1-24

Welch, R.M. (2002) the impact of mineral nutrients in food crops on global health. Plant Soil, 247: 83-90.

Zhang, L., Chen, Z., Wang, J. and Bao, J. (2000) Iodine loss from iodinised salt during processing, sale and consumption. Zhejiang Prev Med. 2000; 12(6): 32-4.

Zhu, Y.G., Huang, Y.Z., Hu, Y. and Liu, Y.X. (2003) Iodine uptake by spinach (Spinacia oleracea L.) plants grown in solution culture: effect of iodine species and solution concentration. Environmental International, 29: 33-37. 